\title{
SIFAT KIMIA TANAH DAN POPULASI KUMBANG TANDUK (Oryctes rhinoceros L.) STADIA PRADEWASA PADA BERBAGAI KEDALAMAN PENEMPATAN TANDAN KOSONG KELAPA SAWIT
}

\author{
Hafiz fauzana $^{1}$, Ayubi Alfasiri ${ }^{1}$, Nelvia Nelvia ${ }^{1}$ \\ ${ }^{1}$ Jurusan Agroteknologi Fakultas Pertanian Universitas Riau \\ Jl. HR. Soebrantas KM 12,5 Panam, Pekanbaru, Indonesia 28293 \\ Email : Fauzana_hafiz@yahoo.co.id ; Mobile; +6285278959292
}

\begin{abstract}
Oil palm is a very significant industrial plant in producing vegetable oils that require high levels of nutrients in its cultivation. Cultivation of oil palm yield can produce industrial waste, the oil palm empty trunks (TKKS) which have the potential to supply nutrients to oil palm land. The placement of empty trunks at various depths is expected can give effect to the population of Oryctes rhinoceros L pre-adult stage and chemical soil properties. This research was conducted on oil palm plantation in PT. Perkebunan Nusantara V Sei Galuh Tapung, Kampar, Riau from July to October 2017. The aim of this research is to examine the effect of empty trunks placement against the Oryctes rhinoceros L population development and chemical soil properties. This research was done using a randomized experiment design complete with the treatment of the depth empty trunks placement (placement of oil palm empty trunks on the ground at the depth of $10 \mathrm{~cm}, 20 \mathrm{~cm}$, and 30 $\mathrm{cm})$ which is repeated four times. The observed parameters include the population of infestation of Oryctes rhinoceros L (population of eggs, larvae and pupae) and soil chemical properties (soil $\mathrm{pH}$, C-organic, N-total, P-total and K-total). The results showed that empty trunks placed below the surface at various depths affected the Oryctes rhinoceros L population. Placement of TKKS depth in the soil cannot be infested by Oryctes rhinoceros L. Placement of empty trunks at the depth of the soil tends to increase $\mathrm{pH}$ (from very acidic categories to acidic categories) and total $\mathrm{K}$ (from the low category to very high category), is not effected on C-organic and N-total and can reduce P-total (from the very high category to the high category) if compared to the placement of empty trunks on the ground.

Key words : Chemical Soil properties, Oryctes rhinoceros L., Oil palm Empty trunks, Soil depth

(c) 2019 Hafiz Fauzana, Ayubi Alfasiri, Nelvia Nelvia
\end{abstract}

\section{PENDAHULUAN}

Kelapa sawit merupakan tanaman industri penting sebagai penghasil minyak nabati, minyak industri, maupun bahan bakar (biodiesel). Provinsi Riau adalah sentra produksi tandan buah segar (TBS) kelapa sawit. Total produksi TBS kelapa sawit di Riau pada tahun 2015 mencapai 8.059.846 ton dengan total luas lahan 2.400.876 ha (Direktorat Jenderal Perkebunan, 2016). Setiap satu ton TBS yang diolah di pabrik kelapa sawit (PKS) akan menghasilkan sekitar 230 $\mathrm{kg}$ TKKS (Naibaho, 1995). limbah padat TKKS selama ini hanya ditimbun atau digunakan untuk mulsa penutup sebagai penyubur tanaman kelapa sawit dengan cara menyebarkan di sekitar pohon kelapa sawit tersebut. Limbah TKKS ini menghasilkan biomasa yang cukup besar pada setiap produksi olahan kelapa sawit di PKS. (Naibaho, 1995). Produksi TBS yang tinggi di Provinsi Riau menjadikan TKKS ini berpotensi sebagai bahan organik apabila dikembalikan sebagai bahan organik pada lahan kelapa sawit dengan tujuan untuk memperbaiki sifat tanah dan penyubur tanaman kelapa sawit.

$$
\text { Hasil penelitian Antari (2013) }
$$

menunjukan bahwa TKKS adalah bahan 
organik yang terbaik dapat memperbaiki sifat tanah, meningkatkan, kelembaban tanah, Meningkatkan C-Organik, N-total, dan menurunkan bulk density (BD), particle density (PD), serta suhu tanah dibandingkan tanpa penambahan TKKS. Berdasarkan hasil penelitian Yunindanova et al. (2013) melaporkan bahwa kompos TKKS yang berumur 8 minggu menghasilkan nilai $\mathrm{N}$-total sebesar $1,34 \%$, nilai $\mathrm{P}$ sebesar $0,08 \%$, nilai $\mathrm{K}$ sebesar 0,24 \%, nilai $\mathrm{Mg}$ sebesar 0,25\%, dan rasio $\mathrm{C} / \mathrm{N}$ sebesar 35,16 yang mampu meningkatkan $\mathrm{pH}$ tanah, KTK tanah dan produksi tanaman tomat pada tanah ultisol. Ullyta (2017) juga melaporkan bahwa lamanya aplikasi TKKS sebagai mulsa berpengaruh tidak nyata terhadap peningkatan $\mathrm{pH} \mathrm{H}_{2} \mathrm{O}$ dan C-organik pada kedalaman tanah 0-15 cm.

Aplikasi TKKS pada area tanaman kelapa sawit disisi lain mendatangkan serangan hama kumbang tanduk, sebagaimana Pujiastuti (2010) melaporkan bahwa aplikasi TKKS pada area tanaman kelapa sawit dapat mengundang hama kumbang $O$. rhinoceros untuk meletakkan telurnya sebagai sumber makanan dari larva $O$. rhinoceros, larva $O$. rhinoceros dapat hidup pada kedalaman tanah 20-30 cm apabila bahan organik sebagai makanannya tercukupi. Handoko et al., (2017) melaporkan bahwa tanaman kelapa sawit yang diaplikasikan TKKS yang dibiarkan menumpuk akan menjadi tempat perkembangbiakan kumbang tanduk (Oryctes rhinoceros L.) dewasa untuk meletakkan telur. Oleh sebab itu diperlukan cara dalam pengaplikasian TKKS agar tidak mengundang kumbang $O$. rhinoceros.

Penempatan TKKS di berbagai kedalaman kelapa sawit diduga dapat mempergaruhi sifat kimia tanah dan infestasi $O$. rhinoceros. Penelitian ini bertujuan untuk mengetahui pengaruh kedalaman penempatan tandan kosong kelapa sawit terhadap sifat kimia tanah dan infestasi kumbang tanduk (Oryctes rhinoceros L.).

\section{BAHAN DAN METODA}

Penelitian ini dilaksanakan di perkebunan kelapa sawit PT. Perkebunan
Nusantara (PTPN) V Sei Galuh Kecamatan Tapung, Kabupaten Kampar dan Laboratorium Ilmu Tanah Fakultas Pertanian Universitas Riau, Jalan Bina Widya kelurahan Simpang Baru Panam, Kecamatan Tampan Pekanbaru. Penelitian dilakukan selama empat bulan yaitu dari bulan Juli 2017 sampai dengan bulan Oktober 2017.

Bahan yang digunakan dalam penelitian ini adalah TKKS, plastik sampel, bahan-bahan analisis kimia tanah, pancang dan kertas label. Alat yang digunakan dalam penelitian ini yaitu, cangkul, tembilang, meteran, gerobak dorong, gancu, ombrometer, ayakan tanah, alat analisis kimia tanah, $\mathrm{pH}$ meter, spektrofotometer dan alat tulis.

Penelitian ini dilaksanakan secara eksperimen yang disusun menurut rancangan acak lengkap (RAL). Perlakuan yang digunakan adalah kedalaman penempatan TKKS (kedalaman $0 \mathrm{~cm}, 10 \mathrm{~cm}, 20 \mathrm{~cm}$ dan 30 $\mathrm{cm}$ ), setiap perlakuan diulang empat kali. Parameter yang diamati adalah $\mathrm{pH}$ tanah $(\mathrm{pH}$ meter), C-organik (pengabuan kering), $\mathrm{N}$-total (kjeldahl), P-total (ekstrak HCL 25\%), K-total tanah (ekstrak HCL 25\%) dan populasi infestasi kumbang $O$. rhinoceros.

Penelitian dilaksanakan dengan menimbun TKKS pada berbagai kedalaman pada plot persegi berukuran 1 x $1 \mathrm{~m}$, dengan kedalaman penempatan sesuai perlakuan TKKS $(0 \mathrm{~cm}, 10 \mathrm{~cm}, 20 \mathrm{~cm}$ dan $30 \mathrm{~cm}$. TKKS yang ditempatkan setebal 1 lapis yang ditempatkan pada gawangan tanaman kelapa sawit selama tiga bulan.

Lokasi penelitian berada di kebun kelapa sawit blok 23 I Afdeling II Perkebunan PTPN V Kebun Sei Galuh. Lokasi ini dipilih berdasarkan adanya serangan hama kumbang $O$. rhinoceros untuk mengetahui pengaruh TKKS yang sudah diaplikasikan terhadap populasi kumbang $O$. rhinoceros. Tanaman kelapa sawit ditanam pada tahun 2012 dengan jenis tanah ultisol famili Aquult berada pada lembah lereng topografi lahan datar penelitian menggunaan area gawangan mati pada area kebun. Tekstur tanah disajikan pada Tabel 1. 
Tabel 1. Komposisi fraksi pasir, debu dan liat tanah di lokasi penelitian

\begin{tabular}{|c|c|c|c|c|}
\hline \multirow{2}{*}{$\begin{array}{c}\text { Kedalaman } \\
\text { tanah } \\
(\mathrm{cm})\end{array}$} & \multicolumn{3}{|c|}{ Jumlah (\%) } & \multirow{2}{*}{ Tekstur" } \\
\hline & Pasir & Debu & Liat & \\
\hline 0 & 33,05 & 18,99 & 47,96 & Liat \\
\hline 10 & 23,89 & 8,41 & 67,70 & Liat \\
\hline 20 & 12,35 & 40,77 & 46,88 & $\begin{array}{c}\text { Liat } \\
\text { berdebu }\end{array}$ \\
\hline 30 & 12,14 & 46,70 & 41,16 & $\begin{array}{c}\text { Liat } \\
\text { berdebu }\end{array}$ \\
\hline
\end{tabular}

Parameter pengamatan meliputi $\mathrm{pH}$ tanah, C-organik, N-total, P-total dan K-total, jumlah populasi $O$. rhinoceros dan jumlah masing-masing stadia pradewasa yang ditemukan. Hasil pengamatan $\mathrm{pH}, \mathrm{C}$-organik, N-total, P-total dan K-total dianalisis secara deskriptif dengan membandingkan sifat kimia tanah pada aplikasi TKKS selama tiga bulan dengan kriteria sifat kimia tanah yang telah baku. Pengamatan populasi O. rhinoceros diamati setiap bulannya sebanyak tiga kali dengan mengamati jumlah populasi $O$. rhinoceros pada setiap plotnya. Data hasil pengamatan dianalisis dengan statistik dengan menggunakan sidik ragam dan uji lanjut BNT pada taraf $5 \%$.

\section{HASIL DAN PEMBAHASAN}

Reaksi tanah $(\mathrm{pH})$

Tabel 2 menunjukkan bahwa penempatan TKKS pada kedalaman tanah yang berbeda menyebabkan $\mathrm{pH}$ tanah meningkat. Kondisi tanah di lapangan umumnya berada dalam kategori sangat masam setelah penambahan TKKS terjadi peningkatam $\mathrm{pH}$. Peningkatan $\mathrm{pH}$ tanah tertinggi terjadi pada penempatan TKKS di kedalaman $10 \mathrm{~cm}$ yang dapat menaikan $\mathrm{pH}$ hingga pada kategoeri agak masam sebesar 2,81 satuan, diikuti penempatan TKKS pada pada kedalaman 20 $\mathrm{cm}$ dan permukaan tanah (kedalaman $0 \mathrm{~cm}$ ) yang dapat menaikkan $\mathrm{pH}$ hingga pada kategori masam masing-masing sebesar 2,19 satuan dan 2,04 satuan, sementara peningkatan terendah terjadi pada penempatan TKKS pada kedalaman $30 \mathrm{~cm}$ sebesar 1,10 satuan yang tidak merubah kategori kemasaman tanah, hal ini menujukan bahwa penempatan TKKS di berbagai kedalaman cenderung dapat meningkatkan $\mathrm{pH}$ tanah.

Tabel 2. Perubahan $\mathrm{pH}$ tanah sebelum dan sesudah penempatan TKKS di kedalaman berbeda (pH meter)

\begin{tabular}{ccccc}
\hline $\begin{array}{c}\text { Kedalaman } \\
\text { penempatan } \\
\text { TKKS }(\mathrm{cm})\end{array}$ & $\begin{array}{l}\text { Sebelum } \\
\text { aplikasi }\end{array}$ & $\begin{array}{l}\text { Kriteria } \\
\text { tanah* }\end{array}$ & $\begin{array}{l}\text { Sifat } \\
\text { aplikasi }\end{array}$ & $\begin{array}{c}\text { Kriteria sifat } \\
\text { tanah* }\end{array}$ \\
\hline 0 & 3,32 & Sangat masam & 5,36 & Masam \\
10 & 3,30 & Sangat masam & 6,11 & Agak masam \\
20 & 3,21 & Sangat masam & 5,40 & Masam \\
30 & 3,33 & Sangat masam & 4,43 & Sangat masam \\
\hline
\end{tabular}

Hasil penelitian Sahputra (2016) juga menyatakan bahwa pemberian bahan organik berupa TKKS dengan kedalaman muka air yang berbeda pada tanah gambut dapat meningkatkan $\mathrm{pH}$ tanah menjadi rata-rata 3,84 satuan.

Peningkatan $\mathrm{pH}$ tanah disebabkan oleh TKKS yang terdekomposisi menghasilkan anion-anion yang dapat meningkatkan $\mathrm{pH}$ tanah. Stevenson (1982) mengemukakan bahwa bahan organik mengandung anion-anion yang dapat mengikat ion-ion $\mathrm{Al}$ dan Fe dalam tanah dan membentuk senyawa kompleks yang sukar larut, akibatnya konsentrasi $\mathrm{Al}$ dan Fe menurun, dengan berkurangnya konsentrasi $\mathrm{Al}$ dan Fe maka hidrogen sebagai penyebab kemasaman tanah pun berkurang, akibatnya $\mathrm{pH}$ meningkat.

Tingginya peningkatan $\mathrm{pH}$ tanah pada penempatan TKKS pada kedalaman $10 \mathrm{~cm}$ dan 
$20 \mathrm{~cm}$ diduga karena dekomposisi TKKS yang berlangsung lebih cepat untuk menaikkan $\mathrm{pH}$ dibandingkan dengan permukaan tanah dan kedalaman $30 \mathrm{~cm}$. Peranan mikroorganisme menunjukkan peranan lebih baik dalam mendekomposisi bahan organik pada kedalaman $10 \mathrm{~cm}$ dan $20 \mathrm{~cm}$ dibandingkan dengan TKKS yang diaplikasikan di permukaan tanah. Saibi dan Tolanggara (2017) menjelaskan bahwa pada kedalaman $10 \mathrm{~cm}$ dan $20 \mathrm{~cm}$ jumlah yang cukup untuk mendekomposisi bahan organik, hal ini karena aerasi yang baik dan ketersediaan oksigennya yang sangat melimpah pada kedalaman 10-20 $\mathrm{cm}$.

\section{C-organik} $\begin{array}{lccr}\text { Tabel } & 3 & \text { menunjukkan } & \text { bahwa } \\ \text { penempatan TKKS } & \text { secara umum dapat } \\ \text { meningkatkan kadar C-organik tanah. }\end{array}$ Peningkatan C-organik tertinggi dicapai pada TKKS yang ditempatkan di permukaan tanah C-organik tanah sebesar $4,23 \%$, diikuti oleh TKKS yang ditempatkan pada kedalaman 30 $\mathrm{cm}$ yang meningkatkan C-organik sebesar
2,26\%. Sementara TKKS yang ditempatkan pada kedalaman $10 \mathrm{~cm}$ dan $20 \mathrm{~cm}$ terjadi peningkatan $\mathrm{C}$-organik tanah berturut-turut sebesar $0,59 \%$ dan $0,18 \%$. Peningkatan TKKS di berbagai kedalaman walaupun dapat meningkatkan C-organik namun peningkatanya tidak setinggi penempatan TKKS di permukaan tanah.

Tingginya kadar C-organik di lokasi penelitian selain didukung karena penempatan TKKS yang lokasinya dekat dengan gawangan mati juga didukung karena tingginya kadar fraksi liat seperti yang tertera pada Tabel 1, diduga fraksi liat tanah mengikat C-organik sehingga jumlahnya tinggi. Putri et al. (2016) menyatakan bahwa kadar fraksi liat didalam tanah sangat berpengaruh terhadap tingginya bahan organik.

Mikroorganisme aerobik berada dalam jumlah yang cukup untuk mendekomposisi bahan organik, hal ini karena aerasi yang baik dan ketersediaan oksigennya yang sangat melimpah pada kedalaman 10-20 cm.

Tabel 3. Perubahan C-Organik dengan penempatan TKKS di kedalaman berbeda (Walkey dan Black)

\begin{tabular}{ccccc}
\hline $\begin{array}{l}\text { Kedalaman } \\
\text { penempatan } \\
\text { TKKS }(\mathrm{cm})\end{array}$ & $\begin{array}{l}\text { Sebelum } \\
\text { aplikasi }\end{array}$ & $\begin{array}{l}\text { Kriteria } \\
\text { tanah* }\end{array}$ & $\begin{array}{l}\text { Sifat } \\
\text { aplikasi }\end{array}$ & $\begin{array}{l}\text { Kriteria sifat } \\
\text { tanah* }\end{array}$ \\
\hline 0 & 8,86 & Sangat tinggi & 13,09 & Sangat tinggi \\
10 & 8,11 & Sangat tinggi & 8,70 & Sangat tinggi \\
20 & 12,30 & Sangat tinggi & 12,48 & Sangat tinggi \\
30 & 14,58 & Sangat tinggi & 16,84 & Sangat tinggi \\
\hline
\end{tabular}

*sumber: (Pusat Penelitian Tanah, 1983)

Tingginya kadar C-organik di lokasi penelitian selain didukung karena penempatan TKKS yang lokasinya dekat dengan gawangan mati juga didukung karena tingginya kadar fraksi liat seperti yang tertera pada Tabel 1, diduga fraksi liat tanah mengikat C-organik sehingga jumlahnya tinggi. Putri et al. (2016) menyatakan bahwa kadar fraksi liat didalam tanah sangat berpengaruh terhadap tingginya bahan organik. Semakin besar jumlah fraksi liat, maka kadar bahan organik pun semakin besar begitu pula sebaliknya. Hal ini juga menunjukkan bahwa pengaruh antara keduanya adalah searah, karena satu variabel menurun, maka variabel lain juga menurun.

Hasil penelitian Antari (2014) yang menyatakan bahwa pemberian bahan organik TKKS sebagai mulsa dapat meningkatkan Corganik menjadi 11,65\%. Afandi et al. (2015) menyatakan bahwa adanya penambahan bahan organik berbanding lurus dengan peningkatan C-organik tanah dan penahan lengas tanah. Karbon merupakan sumber makanan mikroorganisme tanah, sehingga C-organik 
dalam tanah akan memacu kegiatan mikroorganisme.

Perbedaan perubahan C-organik pada kedalaman tanah yang berbeda terjadi dikarenakan proses dekomposisi TKKS pada kedalaman $10 \mathrm{~cm}$ dan $20 \mathrm{~cm}$ dibantu oleh mikroorganisme tanah, Sejalan dengan pendapat Alexander (1977) yang menjelaskan bahwa nisbah $\mathrm{C}$ organik akan menurun dengan waktu karena lepasnya karbon. Mikroba akan menggunakan unsur $\mathrm{C}$ untuk menyusun selnya dengan membebaskan $\mathrm{CO}_{2}$ serta dihasilkan senyawa-senyawa lain sebagai hasil dekomposisi.

\section{N-total}

Tabel 4 menunjukan bahwa kadar Ntotal penempatan TKKS dapat meningkatkan N-total tanah. Peningkatan tertinggi dicapai pada TKKS yang ditempatkan di permukaan tanah yang dapat meningkatkan N-total dari kategori rendah hingga pada kategori sedang sebesar $0,35 \%$, diikuti dengan penempatan TKKS pada kedalaman $10 \mathrm{~cm}$ dan $20 \mathrm{~cm}$ berturut-turut sebesar $0,05 \%$ dan $0,02 \%$ sementara peningkatan $\mathrm{N}$-total terendah dicapai pada TKKS yang ditimbun pada kedalaman 30 $\mathrm{cm}$ sebesar $0,01 \%$. Penempatan TKKS yang pada kedalaman $10 \mathrm{~cm}, 20 \mathrm{~cm}$ dan $30 \mathrm{~cm}$ walaupun dapat meningkatkan $\mathrm{N}$-total, namun peningkatannya tidak dapat merubah kategori N-total tanah dari pada sebelum penempatan.

Hasil penelitian Amin (2015) juga menunjukan bahwa pemberian TKKS di kedalaman biopori berpengaruh nyata terhadap peningkatkan $\mathrm{N}$-total tanah sebesar $0,14 \%$. Situmorang (2017) menjelaskan bahwa peningkatan nilai N-total pada tanah terjadi akibat penambahan TKKS disebabkan oleh dekomposisi dan mineralisasi TKKS yang dilakukan oleh biota tanah, dekomposisi dan mineralisasi dari TKKS yang dilakukan oleh biota tanah dapat menyumbangkan senyawa organik ke dalam tanah.

Tabel 4. Perubahan N-total dengan penempatan TKKS di kedalaman berbeda ( kjeldahl),

\begin{tabular}{|c|c|c|c|c|}
\hline \multirow{2}{*}{$\begin{array}{l}\text { Kedalaman } \\
\text { penempatan } \\
\text { TKKS }(\mathrm{cm})\end{array}$} & \multicolumn{4}{|c|}{ N-total (\%) } \\
\hline & $\begin{array}{l}\text { Sebelum } \\
\text { aplikasi }\end{array}$ & $\begin{array}{l}\text { Kriteria sifat } \\
\text { tanah* }\end{array}$ & $\begin{array}{l}\text { Setelah } \\
\text { aplikasi }\end{array}$ & $\begin{array}{l}\text { Kriteria sifat } \\
\text { tanah* }\end{array}$ \\
\hline 0 & 0,10 & Rendah & 0,45 & Sedang \\
\hline 10 & 0,15 & Rendah & 0,20 & Rendah \\
\hline 20 & 0,41 & Sedang & 0,43 & Sedang \\
\hline 30 & 0,48 & Sedang & 0,49 & Sedang \\
\hline
\end{tabular}

*sumber: (Pusat Penelitian Tanah, 1983)

Peningkatan N-total di permukaan tanah menunjukkan hasil terbaik pada peningkatan $\mathrm{N}$-total dibandingkan TKKS yang ditimbun di bawah permukaan tanah. Adanya faktor dekomposisi oleh makrofauna seperti larva $O$. rhinoceros dan beberapa makrofauna lain yang dijumpai pada TKKS di permukaan tanah menyebabkan N-total meningkat. Kamarudin (2005) menjelaskan bahwa larva $O$. rhinoceros berkontribusi lebih dalam dekomposisi bahan organik dan dapat meningkatkan N-total tanah namun peningkatannya tidak berbeda nyata dibandingkan dengan adanya $O$. rhinoceros.

Peningkatan N-total di kedalaman 10 $\mathrm{cm}$ menunjukkan hasil yang lebih baik dari pada TKKS yang berada pada kedalaman 20 $\mathrm{cm}$ dan $30 \mathrm{~cm}$ karena proses dekomposisi TKKS pada kedalaman $10 \mathrm{~cm}$ berjalan lebih cepat dari pada kedalaman $20 \mathrm{~cm}$ dan $30 \mathrm{~cm}$. Perombakan TKKS yang berlangsung cepat pada kedalaman $10 \mathrm{~cm}$ ini dikarenakan mikroorganisme tanah sebagai dekomposer berada dalam jumlah yang cukup yang menyebabkan $\mathrm{N}$-total meningkat lebih tinggi. Saibi dan Tolanggara (2017) menjelaskan bahwa pada kedalaman $10 \mathrm{~cm}$ dan $20 \mathrm{~cm}$ mikroorganisme aerobik berada dalam jumlah yang cukup untuk mendekomposisi bahan organik, hal ini karena aerasi yang baik dan ketersediaan oksigennya yang sangat melimpah pada kedalaman $10-20 \mathrm{~cm}$. 
P-total

Tabel 5 menunjukan bahwa kadar Ptotal tanah mengalami peningkatan pada aplikasi TKKS di permukaan tanah (kedalaman $0 \mathrm{~cm}$ ) yaitu sebesar $10,81 \mathrm{mg} .100 \mathrm{~g}^{-1}$, dengan kategori P-total tinggi dan tidak terjadi perubahan. Penempatan TKKS di kedalaman $10 \mathrm{~cm}, 20 \mathrm{~cm}$ dan $30 \mathrm{~cm}$ terjadi penurunan Ptotal tanah berturut-turut sebesar 25,51 mg.100g ${ }^{-1}, \quad 27,73$ mg. $100 g^{-1}$ dan 196,60 mg. $100 \mathrm{~g}^{-1}$ dari kategori P-tanah yang awalnya sangat tinggi menjadi kategori tinggi setelah diaplikasikan TKKS.

Peningkatan nilai P-total pada TKKS yang ditempatkan di permukaan tanah disebabkan oleh dekomposisi dan mineralisasi TKKS yang ditempatkan pada tanah. Sejalan dengan pendapat Situmorang (2015) yang menjelaskan bahwa peningkatan nilai P-total tanah disebabkan oleh dekomposisi dan mineralisasi bahan organik TKKS yang dilakukan oleh biota tanah yang aktif dalam melakukan perombakan bahan organik sehingga $\mathrm{P}$ menjadi tersedia di tanah, $\mathrm{P}$ yang diaplikasikan pada tanah gambut pada kedalaman muka air yang berbeda dapat meningkatkan P-total menjadi 359,30 mg.100g1. Minardi (2006) dalam penelitiannya juga menyatakan bahwa asam humat dan asam fulvat yang berasal dari bahan organik berperan menyebabkan pelepasan $\mathrm{P}$ yang terjerap di dalam tanah sehingga meningkatkan ketersediaan $\mathrm{P}$ dalam tanah. Perubahan ini ditunjukkan dengan peningkatan $\mathrm{pH}$ serta terjadinya penurunan aktifitas $\mathrm{Al}$ dan $\mathrm{Fe}$ sebagai unsur logam dalam tanah.

Tabel 5. Perubahan P-total dengan penempatan TKKS di kedalaman berbeda (ekstrak HCL 25\%)

\begin{tabular}{ccccc}
\hline \multirow{2}{*}{$\begin{array}{c}\text { Kedalaman } \\
\text { penempatan } \\
\text { TKKS }(\mathrm{cm})\end{array}$} & $\begin{array}{c}\text { Sebelum } \\
\text { aplikasi }\end{array}$ & $\begin{array}{l}\text { Kriteria } \\
\text { tanah* }\end{array}$ & $\begin{array}{l}\text { Sifat } \\
\text { aplikasi }\end{array}$ & $\begin{array}{l}\text { Kriteria } \\
\text { tanah* }\end{array}$ \\
\hline 0 & 44,01 & Tinggi & sifat \\
10 & 76,52 & Sangat tinggi & 54,82 & Tinggi \\
20 & 76,08 & Sangat tinggi & 48,01 & Tinggi \\
30 & 241,47 & Sangat tinggi & 44,87 & Tinggi \\
*sumber: (Pusat Penelitian Tanah, 1983) & \multicolumn{3}{c}{ Tinggi } \\
\hline
\end{tabular}

Penurunan nilai $\mathrm{P}$ tanah pada penempatan TKKS di kedalaman $10 \mathrm{~cm}, 20 \mathrm{~cm}$ dan $30 \mathrm{~cm}$ diduga terjadi akibat aktivitas mikroba dalam mineralisasi fosfat. Sulasih dan Rahmat (2007) menjelaskan bahwa mineralisasi fosfat organik juga melibatkan peran mikroba tanah melalui produksi enzim fosfatase. Enzim fosfatase berperan pada prosses hidrolisis $\mathrm{P}$ organik menjadi fosfat anorganik $\left(\mathrm{H}_{2} \mathrm{PO}_{4}{ }^{-}\right.$dan $\left.\mathrm{HPO}_{4}{ }^{2-}\right)$ yang tersedia bagi tanaman, namun didalam aktivitasnya fostat dibutuhkan oleh mikroba sebagai sumber energi (ATP) untuk memperbanyak jumlah koloni sehingga kadar P menurun.

\section{K-total}

Tabel 6 menunjukkan bahwa kadar K-total tanah pada setiap kedalaman tanah mengalami peningkatan dibandingkan sebelum aplikasi TKKS, peningkatan tertinggi K-total terjadi pada aplikasi TKKS di kedalaman $10 \mathrm{~cm}$ sebesar $184.39 \mathrm{mg}^{100 \mathrm{~g}^{-1}}$ yang diikuti oleh peningkatan kandungan K-total pada aplikasi TKKS di permukaan tanah dan di kedalaman $20 \mathrm{~cm}$ berturut turut sebesar $173.03 \mathrm{mg} \cdot 100 \mathrm{~g}^{-1}$ dan 50,35 mg. $100 \mathrm{~g}^{-1}$. Penempatan TKKS pada permukaan tanah dan pada kedalaman 10 dan $20 \mathrm{~cm}$ dapat meningkatkan K-total tanah dari kategori rendah hingga sangat tinggi sementara peningkatan paling rendah terjadi pada penempatan TKKS di kedalaman $30 \mathrm{~cm}$ yang meningkat sebesar $40.53 \mathrm{mg} .100 \mathrm{~g}^{-1}$ yang meningkatkan K-total tanah dari kategori sedang hingga sangat tinggi, hal ini menunjukkan bahwa penempatan TKKS dapat meningkatkan K-total tanah. Sejalan dengan hasil penelitian Sahputra et al. (2016) yang menunjukkan bahwa pemberian bahan organik TKKS cenderung meningkatkan kadar Kalium 
pada tanah gambut sebesar 0,07 me. $100 \mathrm{~g}^{-1}$ dengan kedalaman muka air 60-70 cm.

Peningkatan kandungan K-total setelah aplikasi TKKS jelas terlihat pada kedalaman 10 $\mathrm{cm}$ dan pada penempatan TKKS di permukaan tanah namun tidak sebesar pada penempatan TKKS di kedalaman $20 \mathrm{~cm}$ dan $30 \mathrm{~cm}$, hal ini karena adanya proses dekomposisi yang berlangsung lebih cepat pada permukaan tanah hingga kedalaman $10 \mathrm{~cm}$ yang menyebabkan K-total meningkat, hal ini didukung karena kandungan unsur $\mathrm{K}$ yang tinggi yang terkandung pada TKKS.

Saibi dan Tolanggara (2017) menjelaskan bahwa pada kedalaman $10 \mathrm{~cm}$ jumlah mikroorganisme aerobik dekomposer bahan organik sangat melimpah, hal ini karena pada kedalaman $10 \mathrm{~cm}$ masih dekat dengan permukaan tanah sehingga aerasinya menyebabkan ketersediaan oksigennya masih sangat melimpah sehingga dekomposisi bahan organik berlangsung cepat. Semakin dalam tanah maka laju dekomposisinya semakin lambat.

Yunindanova et al. (2013) menjelaskan bahwa peningkatan kandungan Kalium pada tanah akibat pemberian TKKS dikarenakan bahan asal yaitu TKKS yang memang tinggi kandungan Kalium. Hastuti (2009) menerangkan bahwa TKKS terkandung 2,90\% $\mathrm{K}_{2} \mathrm{O}$, yang mana kandungan Kalium ini lebih tinggi dari pada unsur $\mathrm{N}$ yang hanya sebesar $0,80 \%$ dan $\mathrm{P}_{2} \mathrm{O}_{5}$ sebesar $0,22 \%$. Jesus (2012) juga menjelaskan bahwa unsur hara Kalium sangat penting bagi tanaman kelapa sawit, unsur Kalium paling banyak di transfer ke tandan buah, pemupukan Kalium dapat meningkatkan produksi TBS kelapa sawit, sehingga pemberian TKKS dapat meningkatkan kandungan Kalium pada tanah.

Tabel 6. Peningkatan K-total dengan penempatan TKKS di kedalaman berbeda tanah (ekstrak HCL 25\%)

\begin{tabular}{|c|c|c|c|c|}
\hline \multirow{2}{*}{$\begin{array}{l}\text { Kedalaman } \\
\text { penempatan } \\
\text { TKKS }(\mathrm{cm})\end{array}$} & \multicolumn{4}{|c|}{ K-total (mg.100 $\left.\mathrm{g}^{-1}\right)$} \\
\hline & $\begin{array}{l}\text { Sebelum } \\
\text { aplikasi }\end{array}$ & $\begin{array}{l}\text { Kriteria sifat } \\
\text { tanah* }\end{array}$ & $\begin{array}{l}\text { Setelah } \\
\text { aplikasi }\end{array}$ & $\begin{array}{l}\text { Kriteria sifat } \\
\text { tanah* }\end{array}$ \\
\hline 0 & 14,03 & Rendah & 187,06 & Sangat Tinggi \\
\hline 10 & 16,70 & Rendah & 201,09 & Sangat Tinggi \\
\hline 20 & 18,89 & Rendah & 69,24 & Sangat Tinggi \\
\hline 30 & 22,89 & Sedang & 63,42 & Sangat Tinggi \\
\hline
\end{tabular}

\section{Populasi $O$. rhinoceros}

Tabel 7 menunjukkan bahwa penempatan TKKS di berbagai kedalaman hanya ditemukan pada pengamatan bulan ketiga di setiap plot. Penempatan TKKS pada kedalaman $10 \mathrm{~cm}, 20 \mathrm{~cm}$ dan $30 \mathrm{~cm}$ memberikan pengaruh yang berbeda nyata dibandingkan pada penempatan TKKS di kedalaman $0 \mathrm{~cm}$ terhadap populasi $O$. rhinoceros pada TKKS. TKKS yang ditempatkan pada kedalaman $0 \mathrm{~cm}$ (permukaan tanah) ditemui populasi $O$. rhinoceros stadia telur dan larva dengan rata-rata 35,25 ekor di setiap petakan yang diaplikasikan TKKS, sementara pada TKKS yang ditempatkan pada kedalaman tanah $10 \mathrm{~cm}, 20 \mathrm{~cm}$ dan $30 \mathrm{~cm}$ tidak dijumpai adanya $O$. rhinoceros.

Penempatan TKKS dengan ditimbun di bawah permukaan tanah kedalaman tidak dapat dijangkau oleh kumbang $O$. rhinoceros, hal ini diduga karena penimbunan TKKS menyebabkan kumbang betina $O$. rhinoceros TKKS tidak dapat mendeteksi keberadaan TKKS, sehingga tidak satupun $O$. rhinoceros stadia pradewasa dijumpai pada TKKS yang ditempatkan di bawah permukaan tanah. Chapman et al. (2013) menjelaskan bahwa daya tarik serangga terhadap makanan dari suatu jarak tertentu terdeteksi oleh indera serangga, indera penglihatan dan sensor bau memegang peranan penting bagi serangga dalam mendekati makanan. Kebanyakan serangga betina meletakkan telur pada tempat yang memang sumber makanan larva, pengenalan makanan mencangkup berbagai stimulan daya tarik pada jarak tertentu. 
Stimulan daya tarik dapat terjadi dengan penglihatan dan sensor bau pada serangga. TKKS yang ditimbun pada kedalaman $10 \mathrm{~cm}$, $20 \mathrm{~cm}$ dan $30 \mathrm{~cm}$ tidak dapat terdeteksi oleh kumbang $O$. rhinoceros betina, sehingga tidak dapat meletakkan telurnya pada aplikasi TKKS.

Tabel 7. Populasi pradewasa O. rhinoceros stadia pradewasa pada TKKS di berbagai kedalaman

\begin{tabular}{ccccc}
\hline Populasi O. rhinoceros & \multicolumn{4}{c}{ Kedalaman penempatan TKKS (cm) } \\
\cline { 2 - 5 } (ekor) & 0 & 10 & 20 & 30 \\
\hline Bulan ke-1 & 0 & 0 & 0 & 0 \\
Bulan ke-2 & 0 & 0 & 0 & 0 \\
Bulan ke-3 & 35.25 & 0 & 0 & 0 \\
Total & $35.25 \mathrm{a}$ & $0 \mathrm{~b}$ & $0 \mathrm{~b}$ & $0 \mathrm{~b}$ \\
\hline
\end{tabular}

Angka-angka pada kolom yang diikuti dengan huruf yang berbeda menunjukkan berbeda nyata menurut uji BNT pada taraf $5 \%$ setelah ditransformasi dengan $\sqrt{\mathrm{y}+0,5}$

Sasauw (2017) menambahkan bahwa O. rhinoceros melakukan aktivitasnya lebih banyak pada malam hari (nocturnal) dan mengandalkan sensor penciuman untuk menemukan tempat untuk bertelur dan mencari makan. Bau yang dikeluarkan oleh TKKS yang ditimbun di bawah permukaan diduga tidak terdeteksi oleh kumbang $O$. rhinoceros sehingga kumbang betina lebih memilih TKKS yang berada pada permukaan tanah dibandingkan dengan TKKS yang ditimbun di bawah permukaan sebagai tempat bertelur.
Stadia pradewasa kumbang $O$. rhinoceros yang ditemukan

Tabel 8 menunjukkan bahwa populasi

$O$. rhinoceros stadia pradewasa yang ditemukan pada setiap plotnya meliputi stadia telur dan larva, sementara pupa tidak satupun ditemukan pada setiap unit percobaan, hal ini disebabkan karena larva $O$. rhinoceros untuk sampai pada stadia pupa membutuhkan waktu sekitar dua hingga lima bulan, sementara pengamatan populasi $O$. rhinoceros hanya berlangsung hingga tiga bulan

Tabel 8. stadia pradewasa O. rhinoceros yang ditemukan padaTKKS di berbagai kedalaman

\begin{tabular}{lcccc}
\hline \multirow{2}{*}{ Stadia } & \multicolumn{5}{c}{ Kedalaman penempatan TKKS (cm) } \\
\cline { 2 - 5 } & 33 & 10 & 20 & 30 \\
\hline Telur (Butir) & & 0 & 0 & 0 \\
\hline Larva (Ekor) & 0,33 & 0 & 0 & 0 \\
Instar 1 & 1,66 & 0 & 0 & 0 \\
Instar 2 & 0,33 & 0 & 0 & 0 \\
Instar 3 & 2,33 & 0 & 0 & 0 \\
Total (ekor) & 0 & 0 & 0 & 0 \\
\hline Pupa (ekr & 35.25 & 0 & 0 & 0 \\
\hline Total & & &
\end{tabular}

Hasil pengamatan menunjukkan bahwa perkembangan populasi kumbang $O$. rhinoceros populasi telur dijumpai lebih dominan, hal ini menunjukkan bahwa perkembangan populasi $O$. rhinoceros berada pada tahapan awal. Adanya $O$. rhinoceros stadia pradewasa pada TKKS ditentukan oleh ada atau tidaknya pakan untuk larva $O$. rhinoceros. TKKS yang berada di permukaan tanah sebagai pakan untuk larva $O$. rhinoceros tersedia sehingga dengan mudah bagi kumbang sehingga kumbang dapat meletakkan telur pada TKKS yang berada di permukaan tanah. Wardani (2017) menjelaskan makanan serangga akan mempengaruhi perkembangan serangga keberadaan makanan serangga dapat 
dipengaruhi oleh suhu, kelembaban udara, curah hujan dan tindakan manusia, apabila semua faktor sangat mendukung perkembangan serangga maka pertambahan populasi serangga akan sejalan dengan semakin bertambahnya makanan serangga.

Faktor lingkungan seperti curah hujan juga mendukung perkembangan $O$. rhinoceros. Kamarudin et al. (2005) menjelaskan bahwa populasi serangga kadang-kadang berubahubah pada awal musim, terutama oleh faktor lingkungan yang mendukung seperti curah hujan, temperatur, dan kelembaban. Curah hujan berpengaruh terhadap perkembangbiakan $O$. rhinoceros, hasil penelitian menunjukkan korelasi positif hubungan antara curah hujan dan populasi awal instar larva. Nuriyanti (2016) menambahkan bawa kelembaban udara yang tinggi pada musim penghujan menyebabkan kelembaban habitat TKKS menjadi cenderung basah. Larva yang berada pada TKKS sangat cocok hidup dengan habitat TKKS yang basah. Bedford (1980) menjelaskan bahwa suhu perkembangan larva $O$. rhinoceros yang sesuai adalah $27-29^{\circ} \mathrm{C}$ dengan kelembaban relatif $85-$ 95\%. dengan demikian TKKS yang sudah diaplikasikan menjadi tempat yang baik untuk larva hidup dan berkembang.

\section{KESIMPULAN}

Penempatan TKKS pada berbagai kedalaman secara nyata berpengaruh terhadap populasi $O$. rhinoceros. TKKS yang ditempatkan di kedalaman tanah $10 \mathrm{~cm}, 20 \mathrm{~cm}$ dan $30 \mathrm{~cm}$, tidak dapat dijangkau kumbang $O$. rhinoceros untuk meletakkan telurnya.

Penempatan TKKS di berbagai kedalaman tanah cenderung dapat meningkatkan $\mathrm{pH}$ (dari kategori sangat masam menjadi kategori agak masam) dan K-total (dari kategori rendah menjadi kategori sangat tinggi), tidak berpengaruh terhadap $\mathrm{C}$-organik dan N-total dan dapat menurunkan P-total (dari kategori sangat tinggi menjadi kategori tinggi) dibandingkan dengan penempatan TKKS di permukaan tanah.

\section{DAFTAR PUSTAKA}

https://doi.org/10.25077/js.vol.1.1-10.2019
Afandi, F. N., B. Siswanto. dan Y. Nuraini. 2015. Pengaruh pemberian berbagai jenis bahan organik terhadap sifat kimia tanah pada pertumbuhan dan produksi tanaman ubi jalar di entisol ngrangkah pawon, Kediri. Jurnal Tanah dan Sumberdaya Lahan 2 (2) : 237-244.

Alexander, Z. 1997. Introduction to Soil Microbiology. Cornell University. New york.

Amin, M., C. Hanum dan Charlog. 2015. Kandungan hara tanah dan tanaman kelapa sawit menghasilkan terhadap pemberian tandan kosong kelapa sawit (tkks) dan kedalaman biopori. Jurnal Online Agroekoteknologi 3 (2). 558-563.

Antari, R., Wawan, dan G. M. E. Manurung. 2013. Pengaruh Pemberian Mulsa Organik Terhadap Sifat Fisik dan Kimia Tanah serta Pertumbuhan Akar Kelapa Sawit. Skripsi Jurusan Agroteknologi Universitas Riau. Pekanbaru. (Tidak dipublikasikan).

Bedford, G. O. 1981. Control of the rhinoceros Beetle by Baculovirus in h.d. Burgess (ed.), Microbial Control of Pest and Plant Diseases 1970-1980. Academic Press, New York.

Chapman, R. F., S.J. Simpson and A.E. Douglas. 2013. The Insect Structure and Funcion. Cambriedge University Press. New York.

Direktorat Jenderal Perkebunan. 2016. Statistik Perkebunan Indonesia. Direktorat Jenderal Perkebunan. Jakarta.

Handoko, J., H. Fauzana dan A. Sutikno. 2017. Populasi dan Intensitas serangan hama kumbang tanduk (Oryctes rhinoceros L.) pada tanaman kelapa sawit (Elaeis guineensis Jacq.) Belum Menghasilkan. Jurnal online mahasiswa. 4 (1).

Hastuti, B. P. 2009. Pemanfaatan limbah tandan kosong kelapa sawit sebagai teh kompos pada tanaman selada. Buletin Ilmiah Instiper 16 (1): 6-14.

Jesus, J. A. D. 2012. Pemanfaatan Tandan Kosong dan Abu Janjang Kelapa Sawit Sebagai Amelioran terhadap Pertumbuhan Bibit Kelapa Sawit (Elaeis quineensis Jacq.) di Pembibitan Utama. Tesis 
Program Pascasarjana Institut Pertanian Bogor. Bogor (Tidak dipublikasikan)

Kamarudin, N., M.B. Wahid and R. Moslim. 2005. Environmental factors affecting the population density Of Oryctes rhinoceros in a zero-burn oil palm replant. Journal of Oil Palm Research (17): 53-63.

Minardi, 2006. Peran Asam Humat dan Fulvat dari Bahan Organik dalam Pelepasan P Terjerap pada Andisol. Disertasi Program Pascasarjana Universitas Brawijaya. Malang. (Tidak dipublikasikan).

Naibaho, P. M. 1995. Teknologi Pengolahan Kelapa Sawit, Pusat Penelitian Kelapa Sawit. Medan.

Nuriyanti, D.D., I. Widhiono. dan A. Suyanto. 2016. Faktor-faktor ekologis yang berpengaruh terhadap struktur populasi kumbang badak (Oryctes rhinoceros L. ) Jurnal Biosfera. 33 (1). 13-21.

Pujiastuti, Y. 2010. Tingkat populasi dan kebugaran Oryctes rhinoceros L (Coleoptera : Scarabaeidae) di perkebunan kelapa sawit (Elaeis guineensis Jacq.). Prosiding Seminar Nasional Penelitian bidang Pertanian Palembang.

Balai Penelitian Tanah. 2009. Petunjuk Teknis Analisis Kimia Tanah, Tanaman, Air dan Pupuk. Badan Penelitian dan Pengembangan Pertanian. Bogor.

Putri, A.M.S., Suryani dan N. Widyorini. 2016. Hubungan tekstur sedimen dengan kandungan bahan organik dan kelimpahan makrozoobenthos di muara sungai banjir kanal timur Semarang. Indonesian Journal of Fisheries Science and Technology 12 (1): 75-80.

Sahputra , R. Wawan dan E. Anom. 2016. pengaruh kedalaman muka air tanah dan bahan organik terhadap ketersediaan hara dan pertumbuhan tanaman kelapa sawit
(Elaeis guineensis Jacq) di lahan gambut. Jurnal Online Mahasiswa 3 (1): 1-15.

Saibi, N. Dan A.R. Tolangara. 2017. Dekomposisi serasah avecennia lanata pada berbagai tingkat kedalaman tanah. Jurnal Techno 06 (01): 55-63.

Sasauw, A., J. Manueke dan D. Tarore. 2017. Populasi larva Oryctes rhinoceros (Coleoptera: Scarabeidae) pada beberapa jenis media peneluran di perkebunan kelapa Kecamatan Mapanget Kota Manado. Cocos 1 (1).

Stevenson, F.T. 1982. Humus Chemistry. John Wiley and Sons. Newyork.

Sulasih dan Rahmat. 2007. Aktivitas fosfatase dan pelarutan kalsium fosfat oleh beberapa bakteri pelarut fosfat. Biodiversitas 8 (1): 23-26.

Ullyta, A., I.T. Mahbub dan H. Nasution. 2017. Dampak Aplikasi Mulsa TKKS terhadap Sifat Tanah dan Perakaran Kelapa Sawit di Kebun PT. Sari Aditya Loka 1, Kecamatan Air Hitam, Kabupaten Sorolangun. Skripsi Jurusan Agroekoteknologi Fakultas Pertanian Universitas Jambi. Jambi (Tidak dipublikasikan).

Wardani, N. 2017 Perubahan iklim dan pengaruhnya terhadap serangga hama. Prosiding Seminar Nasional Agroinovasi Spesifik Lokasi Untuk Ketahanan Pangan Pada Era Masyarakat Ekonomi ASEAN. Lampung.

Yunindanova, M.B., H. Agusta dan D. Asmono. 2013. Pengaruh tingkat kematangan kompos tandan kosong sawit dan mulsa limbah padat kelapa sawit terhadap produksi tanaman tomat (Lycopersicon esculentum mill.) Pada tanah ultisol. Jurnal Ilmu Tanah dan Agroklimatologi 10 (2). 91-100. 